\title{
Guerilla Marketing Strategies of Neochurches in Cameroon
}

\author{
Francis Mbah Takwi, Bejanga Etonde Abene Sharon, Nchise Delphine Nchang, Kiven Cynthia
}

Faculty of Business Management and Sustainability, Information and Communication Technology University USA, Yaounde, Cameroon

Email address:

francis.takwi@ictuniversity.org (F.M. Takwi), bejanga_sharon@yahoo.com (B. E. A. Sharon), nchise.nchang@ictuniversity.org (N. D. Nchise), kiven.cynthia@ictuniversity.org (K. Cynthia)

\section{To cite this article:}

Francis Mbah Takwi, Bejanga Etonde Abene Sharon, Nchise Delphine Nchang, Kiven Cynthia. Guerilla Marketing Strategies of Neochurches in Cameroon. American Journal of Operations Management and Information Systems. Vol. 5, No. 3, 2020 , pp. $49-55$. doi: 10.11648/j.ajomis.20200503.13

Received: September 6, 2020; Accepted: September 23, 2020; Published: September 29, 2020

\begin{abstract}
The subject of this thesis is a phenomenon of guerrilla marketing, an innovative and unconventional form of marketing that emerged relatively recently and became a popular tool of marketing. In Cameroon there have been the opening of many new churches, especially the Pentecostal and evangelical churches who aim at the prosperity gospel. Neochurches are an offspring of the traditional churches with their leaders having a celebrity status and miracles, deliverance and prosperity their main market offerings. Most of these churches have not had significant growths in terms of membership as compared to the traditional churches. There are 89 religious denominations in Cameroon. Cameroon is you see so many churches opening and ending up w very poor membership growth and after 3 or 4 years they shut down. Also if new churches follow the various steps on how to attract a crowd and keep them as permanent members of their churches most new churches in Cameroon will excel in their numbers and membership. The main aim of this study to explore the marketing strategies used by these churches to win new members and keep existing ones and propose innovative marketing strategies to improve on their market position. The results from this exploratory study ahows that here is evidence to prove that all new churches need a good marketing plan to succeed and avoid stagnant growth or shutting down due to few membership in the churches. Marketing is necessary for all organizations both profit making and non profit making organizations and hence churches are not an exclusion. Most neochurches in Cameroon focus to pull a crowd to the Sunday services and special events like crusades and retain the existing members by overt signs of miracles, deliverance, testimonies of prosperity and inspiring massages. It is recommended that these Neochurches should exploit the social media as one of the simplest ways to win in members into their churches and also maintain a fragrant media presence.
\end{abstract}

Keywords: Innovative Marketing, Church Business, Guerilla Marketing Strategies

\section{Introduction}

While most neochurches in Cameroon think marketing strategies is not relevant for their growth of membership, hence a slow or stagnant growth, there is evidence to suggest how marketing strategies can help resolve this problem.

In this introduction we will be talking about key terms we will be using through this term paper. We will also bring light to the topic and how we plan to show how the problem faced by neochurches can be resolved.

First of all "marketing is the business process of identifying, anticipating and satisfying customers' needs and wants. Marketing can also be defined as the management of exchange relationships [5]. Generally when we talk of the marketing strategy we automatically think of the marketing mix. The marketing mix helps to understand the product or service which has to be offered and how to plan on a successful service or product offering. The marketing mix involves the 4 P's, which are Product, Price, Promotion, and Place. [7]

Going back to the topic which is the marketing strategy of neochurches in Cameroon, the term Neochurches simply means new revival churches in Cameroon.

\section{Neochurches in Cameroon}

A Jamaican Baptist missionary called Joseph Merrick who was by assisted Joseph Jackson Fuller, established the first successful mission on the Cameroon coast of Africa. in the year 1844 Merrick visited Bimbia and spoke to King William 
of the Isubu people to request permission to establish a church on the mainland. Merrick founded the Jubilee Mission in 1844 and over the next four to five years, translated parts of the New Testament into the Isubu language. Merrick work set road for Alfred Saker to make further progress in Cameroon after his death. [13]

There are a lot of missionaries who came to carry out their missions of evangelization which include George W. Schwab who was a Presbyterian missionary, Franziskus Hennemann, Pallottine, Heinrich Vieter just to name a few of them who came to Cameroon to administer the word of God.

In present day, so many pastors go for trainings which permit them to open new churches and start preaching the word of God and trying to win souls for Christ. You can find them at every street in any town in Cameroon. Many Cameroonians have problems and hence they turn to find refuge in the house of God to share their problems through prayer and seek God's face. They took it upon themselves to endure hard times that even the natives suffered in order to impact in them the knowledge of Jesus Christ and the word of God. The legacy of these humble men has completely been overwhelmed by the more self-centred doctrines, which most pastors of this generation preach. At the moment, it is unclear how many churches exist in Cameroon (the legal and the illegal) apparently due to the absence of data. But government that has maintained a nonchalant attitude to the exponential growth of churches is now resolute on weeping out those it terms "illegal churches". Cameroon generally enjoys religious tolerance following the 1990 law on Freedom of Association. Since then, there has been a dramatic increase in the number of religious organisations in the country.

With this so called freedom been put down, the Ministry of Territorial Administration and Decentralisation published a list of registered churches which is as follows;

Table 1. List of approved churches and their headquarters.

\begin{tabular}{|c|c|c|}
\hline Serial No. & Name & Headquarters \\
\hline 1 & Société Baptiste Missionnaire Européenne (Swiss) & Zurich \\
\hline 2 & Assemblée Chrétienne Témoins du Christ & Douala \\
\hline 3 & Mission Catholique Romaine & Yaounde \\
\hline 4 & Presbyterian Church in Cameroun (P. C. C.) & Buea \\
\hline 5 & Eglise Presbytérienne Camerounaise (E. P. C.) & Yaounde \\
\hline 6 & Eglise Protestante Africaine du Cameroun (E. P. A.) & Lolodorf \\
\hline 7 & Eglise Evangélique Luthérienne du Cameroun & Ngaoundere \\
\hline 8 & Apostolic Church of Cameroon & Kumba \\
\hline 9 & Eglise Fraternelle Luthérienne du Nord Cameroun & Kaele \\
\hline 10 & Full Gospel Mission & Muyuka \\
\hline 11 & Global Frontiers Church & Kumba \\
\hline 12 & Assemblée Spirituelle Nationale des Béhaistes & Limbe \\
\hline 13 & Union des Eglises Evangéliques au Nord Cameroun & Mokolo \\
\hline 14 & Eglise Presbytérienne du Cameroun Orthodoxe (E. P. C. O.) & Yaounde \\
\hline 15 & Union des Eglises Baptistes du Cameroun (U. E. B. C.) & Douala \\
\hline 16 & World Wide Mission & Muyuka \\
\hline 17 & Eglise du Christ & Kumba \\
\hline 18 & La Vraie Eglise de Dieu du Cameroun & Yaounde \\
\hline 19 & Eglise Baptiste Camerounaise (E. B. C.) & Douala \\
\hline 20 & Congrégation Baptiste Camerounaise & Douala \\
\hline 21 & Eglise Evangélique du Cameroun & Douala \\
\hline 22 & Association Culturelle Islamique du Cameroun (A. C. I. C.) & Yaounde \\
\hline 23 & Eglise Anglicane & Douala \\
\hline 24 & Cameroon Baptist Convention (C. B. C.) & Bamenda \\
\hline 25 & Mission de l'Eglise Evangélique Camerounaise & Douala \\
\hline 26 & Lutheran Church of Cameroon & Kumba \\
\hline 27 & Eglise Baptiste Nationale du Cameroun & Minyungu \\
\hline 28 & Eglise Biblique de la Vie Profonde & Yaounde \\
\hline 29 & Association Solidaire de la Vocation Islamique du Cameroun (A. S. S. O. V. I. C. & Yaounde \\
\hline 30 & Eglise Universelle de Dieu & Yaounde \\
\hline 31 & Eglise Néo-Apostolique du Cameroun & Yaounde \\
\hline 32 & Eglise Jean Baptiste du Cameroun & Sangmelima \\
\hline 33 & Union Islamique du Cameroun & Douala \\
\hline 34 & Jehovah Witnesses in Cameroon & Yaounde \\
\hline 35 & La Voie au Cameroun & Yaounde \\
\hline 36 & Apostolic Faith Church & Bangem \\
\hline 37 & Eglise Messianique et Evangélique du Cameroun & Yaounde \\
\hline 38 & The Church of Jesus Christ of Later Day Saints & Yaounde \\
\hline 39 & Mission Chrétienne du Cameroun & Nko'emvon \\
\hline 40 & The Grace Bible Church in Cameroon & Yaounde \\
\hline 41 & Church of God of Prophecy & Kumba \\
\hline 42 & The Native Church of the Cameroon & Ndom Bakossi \\
\hline 43 & Union des Eglises Adventistes du Septième Jour en Afrique Centrale & Yaounde \\
\hline
\end{tabular}




\begin{tabular}{lll}
\hline Serial No. & Name & Headquarters \\
\hline 44 & Union Baptiste Camerounaise & Douala \\
45 & Mission Evangélique Vie et Paix du Cameroun & Douala \\
46 & Eglise Pentecotiste Chrétienne du Cameroun & Yaounde \\
47 & La Sainte Métropole gréco-Orthodoxe du Cameroun & Yaounde \\
\hline
\end{tabular}

\section{Marketing Strategies of Neochurches in Cameroon}

In this paragraph we will be talking on the marketing strategies which new churches come up with to help boost their membership and help grow their churches.

1) DOOR TO DOOR PREACHING: In Cameroon we notice that wen a new church in a quarter opens, they usually send out members to do what they call evangelism where they move from door to door of peoples houses, shops, offices etc. So as to meet with people on one on one and preach about the gospel of Christ. After this preaching, for those who were welcoming to the preacher, they are now invited to their church for maybe the next service on a Sunday and they are also told about the weekly church services which will be held for those who cant make it on Sunday. Sometimes this works because the preachers who go out for evangelism are usually very persuasive and they make the listener believe that coming to that church will add spiritual value to their life. At the same time not everyone is always receptive to give a listening ear. [6]

2) SHARING OF BROCHURES: These Pentecostant churches in Cameroon also share out brochures which contain information about their church to help raise awareness to people on the streets, homes, hospitals and everywhere they can find people and have access to. They even force you to take the brochures when they meet you along the street. These brochures carry the name of their ministry, the services which will take place on a weekly basis, numbers of the resident pastors for those who need clarification or personal information from the church.[7]

3) PREACHING PROMISING MESSAGES: During their services. They preach almost the same thing. They tell their members what they want to hear. Their pastors are so gifted in convincing people and preaching promising messages which gives the members hope. Some of their messages sound like this; this year all unmarried women will find husbands in Jesus name, If you are looking to travel and have been having difficulties getting a visa, this year in Jesus name you will get a visa. Not saying the messages are empty because some of the pastors are genuine but also a lot of them just sweet talk members so as to receive gifts from them as sacrifices to our creator God. [4]

4) ORGANISING OF EVENTS: These new churches also organize events during the course of the years. Some of the events include single and happy programs where single people looking for spouses are happy to attend and work on themselves in preparation for their partners. You also have Christmas and end of year programs, Breakthrough and disconnecting from ancestral curses programs, deliverance programs.

Although these strategies above seem to work, some churches does succeed to grow and end up having very sparse members during the course of their existence because these new churches hardly have a very well defined and effective marketing strategy. They seem to just do what the others do and hope to succeed so it is like a probability game.

Marketing/Promoting will truly build distinction between tiny attendances and a thriving church community. In these paragraphs we are going to be bring out many methods that neochurches in Cameroon ought to follow to draw in members to their churches and moreover as retentive them. [1].

1) Try to travel on the far side Sunday Services

Most neochurches in Cameroon specialise in pull a crowd to the Sunday services and take a look at to retain the new members throughout the service. This somehow limits them. once we think of promoting methods we'd like to own one thing to promote. It's a far better plan to organise events outside of standard Sunday service. And if you have got the space, to run huge events moreover. Of course, this will this may\} be community gatherings that could pull the eye of the population. the purpose is to actually attract folks outside of these hours to create a community around your church.

2) Most new churches in Cameroon turn to ignore the normal means of promoting. It's true that exploitation social media is one among the simplest ways that to draw in members to a church however the older generation aren't tech-savvy. This wherever the normal marketing comes in. One awing means of reaching this older cluster is thru publicity house in native newspapers. this can facilitate boost attendances. Neochurches ought to make sure that they mix their methods by posting concerning events like these on social media, so you attract attendees of all ages. observing associate example we are going to see however Winners Chapel, once it came to Cameroon they weren't as huge as they're not, it took them years of promoting and implementing an excellent team to make sure the expansion of their members.

3) Recruiting a decent dynamic promoting team: Most churches particularly the new one in Cameroon turn to pull away from the very fact that they need promoting skills and do a lot of promoting to urge church members. I believe this can be owing to the notion that they are doing not to come up as being a business entity however in essence they're. it's true that they're don't have the only purpose of getting customers however members who are going to be won by Christ, however 
they have promoting methods to draw in and retain these members if not their numbers can keep falling or stay stagnant and that they cannot grow. Recruiting a decent promoting team in an exceedingly church surroundings is extremely simple. 1st of all you would like to grasp your members interest. Most church members are willing to usher in the worth they need for the work of Christ the saviour. All the church leader has got to do is raise and plenty of folks can volunteer to be a part of the team. once the promoting vision of the church has been forged and therefore the decision to volunteer has been done, church leaders ought to ensure the presentation on increasing your church's marketing strategy is exciting and provoking. facilitate interested members perceive they're going to be an important a part of helpful to the unchurched and serving to them discover and build a relationship with Christ. If they perceive the importance of effective church promoting, they're way more seemingly to stay with it. second making a form which is able to have straightforward queries like what proportion time are you willing to place into the promoting exercise day after day, what are the distinctive skills and strengths you have?, however will we tend to inspire you or compensate you for employment well done? of these answers can assist you apprehend your limitations as regards the promoting pan and facilitate set up for unseen circumstances. [7]

When knowing the strengths and weaknesses of your volunteers you ought to forever speak positive things to the team and praise them soften as doable. this can be key to keeping your volunteers and additionally it a key to a productive strategy. Its superb however valuable and provoking a straightforward thanks are often.

4) Creating A Church promoting set up

There's a statement which goes failing to set up is aiming to fail. The success of a marketing set up for neochurches in Cameroon depends heavily on the kind of promoting strategy they are available up with.

Marketing will facilitate your church go from invisible to visible in your community. For the simplest come on your investment, specialise in making persistent campaigns that have constant look and feel across each space, from spam postcards to the banners outside your church.

A good promoting strategy for any new church ought to embody the following;

Budget could be a foundational component of a good church promoting set up. It's vital to commit associate adequate quantity of funding to your efforts so as to examine positive returns on your investment (i.e. guests coming back through your doors). [2]

A budget is extremely necessary for any strategy. For neochurches to reach the promoting strategy they must make sure the following. what proportion can you pay on the promoting outreach? you would like to be in a position be able to apprehend the precise quantity you're willing to out into the promoting set up. last the church leader has got to be specific on however the funds are going to be allotted. for instance if you propose on doing publicity with banners, a specific quantity ought to be allotted for that activity. If flyers are to be written, associate quantity ought to be allotted for that activity. This helps to facilitate the progress of the promoting plans by making certain that adequate preparation is completed and funds are out there once required at a specific time.

A calendar is extremely necessary for any promoting strategy particularly for brand spanking new churches. you ought to be able to set up what percentage events you propose to organise within the 1st year of gap the church. In creating a calendar the promoting team ought to return up with events or activities that ar best for his or her strategy and can facilitate pull a crowd that may later become members of their church. they need to onside they're operating inside a budget to an inventory of preference is often vital.

For neochurches to succeed in their marketing strategy they should be able to determine at least five campaigns or efforts to put into their annual spending. Below is a common seasonal example, that new churches could use:

1) January and February -New Years/Valentine's Day

2) March and April -Easter

3) May -Mother's Day

4) August and September -Back to Church

5) October -Harvest

6) November and December -Advent/Christmas

When finalizing with the campaign a good performance assessment has to be done to see the results which have been produced as a result of their actions. When they can be able to track which campaign led to the highest number of new members; they can now use their budget to focus on this and yield better results in the future. Also the process of tracking your success is very important because it helps reduce the spending on money on things which wont lead to positive results and keeps you working within your budget.

For neochurches to succeed they should be able to come up with event plans. Events help to engage with members and people in the neighbourhood and they go beyond the regular Sunday service. In marketing have personal relationships with clients helps to boost the marketing tool. Relationship marketing can easily be developed from these events churches organise and this is a plus and a way forward toward growing and maintain church membership. [11] They help people connect with you, understand your message, and become involved with your church. Here are a few ideas for outreach events:

Holiday/Celebration Sermon Series

1) Christmas

2) Easter

3) Thanksgiving

4) Mother's Day

5) Guest Speaker or Special Event

6) Movie Nights

Volunteer Events

1) Coat drives

2) Community clean-up 
3) Shelter support

4) Back-to-School Drive

5) Parents' Night Out

6) Harvest Festival/Halloween Alternative

Tools

A portion of your overall budget should be applied to the tools you use for your outreach efforts. These refers to the methods you'll use to advertise your events and make your church known to your community. It's important to invest in a variety of approaches that reaches your audience in several different areas of their lives. Neochurches have to make sure that your message and design are consistent across every piece.

Another important thing neochurches need to consider when doing a marketing strategy is to decide the tools, which will be used for the campaign. Some examples of tools, which neochurches in Cameroon should use, involve the following;

1) Using direct mail is a very effective church marketing tools It helps you easily reach people in your area and invite them to visit your church. Nowadays most people check their mails almost everyday, which mean people are highly likely to see your church postcard. It will be handy to add the church map and service times on the postcard. Another practice is adding a gift. This will attract people. Everyone loves gifts.

2) The use of Invitation Cards too is a very good tool. Neochurches should be able to provide their marketing team with invite cards, which will serve to share knowledge on the existence of the church and the value it will bring to the lives of people. About $70 \%$ of people nowadays would rather prefer a personal invite from a friend or family member for any occasion so an invite cards comes to do the magic.

3) Another tool is banners and signs. Using indoor and outdoor banners and signs helps to inform passer-by and members of upcoming events and it also plays a great role in getting the church noticed by those who have a glance of the sign or the banner.

4) Using Social media is a great tool. Creating a church websites, and email marketing are all tools you can use to share your event. For example in Cameroon to start a business on social media there is a lot of market on apps like Facebook and Instagram. We live in a generation where technology is very advance and digital media is the new market place. So utilizing these apps to get awareness of your church will be a positive impact on the growth of the church.

When a good marketing plan is established, the next thing to do is to focus on the importance of helping visitors become new members. First impression matters a lot. After giving a good impression to visitors through the events organised the next problem is to ensure that these visitors become permanent members. [10]

Most a times almost 90 per cent of visitors will not return to the new churches after the event if the churches do not put in place a strategy to turn the visitors into members. The way you treat guests on their visit will have a big impact on their future decisions to attend your church permanently or not. Some of the things new churches should do include;

Ensure to greet every new visitor. Tending a new church can be intimidating; it's therefore vital to help make every new person feel at home as they walk into the door. To do this a team of greeters has to be created and they should know the goal is to be friendly and greet with a warm smile. It important to choose volunteers who know how to read people and are outgoing and warm. Give them a gift.

Another strategy is to give each new visitor a gift to show your appreciation for his or her time and presence. The gifts could be books, devotionals, fans with the logo and church information engrafted on it, hankerchieves, coffee mugs, agendas, pens or any item which could come in handy for the visitor and help them remember it as a souvenir of their presence. Gifts create positive associations with your church and they can serve as a physical reminder of your hospitality after guests go home.

It is important to Hand out new visitor cards.

These cards, which are handed out to visitors, are used to fill in their information like their names, their phone numbers, their addresses, email and other important information which can be used to reach them. Also the card should have a questionnaire, which helps them tell us what they are looking to seek from the church. This information on the cards will be used to invite them for future events.

Offering Snacks and refreshments to new comers.

Offering refreshment could be a good way to entertain new visitors in neochurches. Imagine after a long service and you are offers some cool drinks or coffee or any snack, This simple gesture goes a long way. This permits them to linger for some time after the service and get to know the other members of the church. In addition to making guests feel at home, they'll create connections that can't be beat when it comes to building relationships because they develop naturally through fellowship. [11]

The last thing is ensure proper follow up. In these recent days following the first visit are critical to connecting with your visitors. Because the key is to make every contact personal and not to rely solely on electronic communication. Some follow steps, which can be used to reach out to people who have attended your event or service, include the following;

1) Have the pastor send a personal thank you email the next day.

2) Make a welcome call the following evening after the event or service.

3) Send out an email at the end of the week inviting them to the next service or event. This is feasible because at the end of each service or event new members leave their information the visitors card.

4) Text your visitor after two weeks to check in.

5) Other tips which neochurches in Cameroon should use to be able to retain members after hosting and event is the organising of monthly new visitor welcome lunch. Imagine a church, which ensures that after one month of 
new attendees they hold a meeting for them to get feedback on how they feel about their stay in the church. This will have a positive feedback for the church.

6) Also having a new visitor booth, which is purpose, is to share important information and also to give out welcome gifts to the first timers. This is practiced in one of the pentecostant churches here in Cameroon called Winners Chapel. And honestly is a good strategy. Make sure your church is always clean and inviting.

\section{Challenges Churches Face}

Despite these marketing strategies which new churches come up with, they still face certain challenges. Some of them include;

1) Slow growth rate: They are unable to meet almost half of the number of members they envisioned in their plan at the start of the church. Getting members at the beginning seems easy and feasible but retaining them is a huge problem. Christians seem to move from church to church in search of miracles hence these new churches cant grow in numbers.

2) Dissatisfaction from members: This is constantly the order of the day in these new churches. The reason is because churches nowadays make so many promises at the start when they find new members just because they want them to be part of their church. But at the end of the day when they cant meet the needs of these members, the members turn to leave and say bad things about the church.

\section{Conclusion and Recommendations}

After taking a close look at all the information above, I strongly believe that most new churches in Cameroon do not have effective marketing strategies and thus they are unable to grow or have a large membership in their churches. The reason I say so is because if most churches actually followed good marketing strategies they will be able to start small and end up being able to attract many members to their church and retain them. But what is instead the order of the day in Cameroon is you see so many churches opening and ending up $\mathrm{w}$ very poor membership growth and after 3 or 4 years they shut down. Also if new churches follow the various steps on how to attract a crowd and keep them as permanent members of their churches most new churches in Cameroon will excel in their numbers and membership.

Most neochurches in Cameroon think marketing strategies is not relevant for their growth of membership, hence a slow or stagnant growth, with all the different tools. Marketing strategies are very vital in early stages of any church and how this can bring positive results because they are very doable.

In conclusion, marketing strategies for neochurches is a powerful way to help you increase your outreach and minister to your community. Marketing as well helps you let people know that your church is available to help them with questions they may have about God and faith. What most neochurches fail to understand is the fact that with a good and dynamic team, a strategic plan, and a very good first impression, this can helps them connect with people are not yet members of their church. So to conclude we will look at the advantages of effective marketing strategies for neochurches in Cameroon.

1) One very important advantage of a marketing strategy is the fact they are research based and they do not depend on gut feelings or instincts which means they are reliable and might definitely get you desired results.

2) Another advantage of using marketing strategies for neochurches in Cameroon is the fact they help the churches to work with their vision and align themselves to the results they aim to achieve.

3) When neochurches in Cameroon decide to establish effective marketing strategies to help maintain and attract growth, this procedure goes to help them identify their strengths and weaknesses. Also gives insights on their opportunities and helps them work on these weaknesses since they can easily be identified for example when building the marketing team from volunteers in the church, They might realise that they don't have competence for outspoken people who are willing to go around during their seasonal events and prospect so they can budget to recruit people to do so.

By and large there is evidence to prove that all new churches need a good marketing plan to succeed and avoid stagnant growth or shutting down due to few membership in the churches. Marketing is necessary for all organisations both profit making and non profit making organisations and hence churches are not an exclusion.

\section{References}

[1] Belch George Eugene, Belch Michael A. 2014. Advertising and promotion: an integrated marketing communication perspective. McGraw-Hill.

[2] Clow E. Kenneth, Baack E. Donald 2018. Integrated Advertising, Promotion, and Marketing Communications. Prentice Hall.

[3] Curran, J. and J. Seaton, 2017. Power without Responsibility: Press and Broadcasting in Britain. 5th Edition Routledge, USA. pp: 432.

[4] Derbaix Christian M, Vanhamme Joelle, 2014. Inducing wordof-mouth by eliciting surprise -a pilot investigation. J Econ Psychology (24): pp. 99-116.

[5] Egan John 2017. Marketing Communications. Cengage Learning.

[6] Gallagher, B 2014. Guerilla marketing and branding. CA: Marketing Turkiye Press.

[7] Kotler Philips, Armstrong Gary, Saunders John, Wong Veronica 2011. Principles of Marketing. Financial Times/ Prentice Hall; 3 edition.

[8] Levinson, Jay Conrad 2018. Guerilla Marketing. Boston, New York. Houghton Mif-flin Company. 
[9] Levinson Jay Conrad 2016. Guerrilla marketing: put your advertising on steroids. Morgan James publishing.

[10] Levinson Jay Conrad, Lautenslager Al 2019. Guerilla Marketing in 30 Days, Second Edition. Entrepreneur press.

[11] Tung Mao Tse, Mao Zedong, Griffin Samuel, 2018. On Guerilla Warfare. University of Illinois Press. Baker, Micheal the strategic Marketing Plan Audit 2008.

[12] https://appinstitute.com/church-marketing-ideas/.

[13] https://en.wikipedia.org/wiki/Joseph_Merrick_(missionary).

[14] https://emergingcameroonnow.blogspot.com/2013/08/list-ofapproved-churches-in-cameroon.html.
[15] About AMA. American marketing association [online]. Available $<$ https://www.ama.org/AboutAMA/Pages/About.aspx > (retrieved 2020-04-10).

[16] The Origin of the Marketing Concept. Uriel.org [online]. Available at: <http://www.uriel.org/brand-management/theorigin-of-the-marketing-concept/> (retrieved 2020-04-10).

[17] Types of guerrilla marketing. GuerrillaOnline.com [online]. Available at: <http://www.guerrillaonline.com/cs/GuerrillaMarketing-types-65.htm> (retrieved 2020-04-10). 